\title{
Basic Statistics
}




\title{
Basic Statistics \\ for medical and social science students
}

\author{
A. E. MAXWELL \\ Professor of Psychological Statistics, \\ Institute of Psychiatry, University of London
}

(6)

LONDOIN

CHAPMAN AND HALL

A Halsted Press Book

John Wiley \& Sons, New York 
First published in 1972 by Penguin Books Ltd as Basic Statistics in Behavioural Research This Science Paperback edition first published 1978 by Chapman and Hall,

11 New Fetter Lane, London EC4P 4EE

(C) A. E. Maxwell

Softcover reprint of the hardcover 1 st edition 1978

ISBN-13: 978-0-412-15580-2 e-ISBN-13: 978-94-009-5804-3 DOI: 10.1007/978-94-009-5804-3

This paperback edition is sold subject to the condition that it shall not, by way of trade or otherwise, be lent, re-sold, hired out, or otherwise circulated without the publisher's prior consent in any form of binding or cover other than that in

which it is published and without a similar condition including this condition being imposed on the subsequent purchaser

All rights reserved. No part of this book may be reprinted, or reproduced or utilized in any form or by any electronic, mechanical or other means, now known or heareafter invented, including photocopying and recording, or in any information storage and retrieval system, without permission in writing from the Publisher

Distributed in the U.S.A. by Halsted Press a Division of John Wiley \& Sons, Inc., New York 


\section{Contents}

Preface 9

1 Some Common Types of Investigation 13

2 Measurement 28

3 Some Simple Descriptive Statistics 41

4 Elementary Sampling Theory 53

5 Elementary Concepts of Probability 60

6 Contingency Tables and Tests of Association 73

7 Correlation and Regression 79

8 Simple Tests of Significance 92

9 Analysis of Variance 103

10 Recording Data on Punch Cards 111

Appendix 1 The Normal Distribution Function 117

Appendix 2 The $t$-Distribution 118

Appendix 3 Percentage Points of the $\chi^{2}$

Distribution 119

Appendix 4 The Variance Ratio $(F) 5$ Per Cent

Points 120

Appendix 5 The Variance Ratio $(F) 1$ Per Cent

Points 121

References 122

Index 125 


\section{Preface}

For many years now I have been required to give a series of elementary lectures on statistics to medical students about to undertake a postgraduate course in psychiatry. The declared aim of the course, for which very limited time was available, was to provide the students with some initial understanding of the statistical terminology and elementary techniques to which other teachers, in particular psychologists and sociologists, would be likely to refer in the course of their lectures. The task was tricky for two reasons. In the first place most of the students involved, despite their best intentions, had forgotten their school mathematics, and secondly no textbook existed at the right level of difficulty which contained examples appropriate to these students' needs and experience.

The present book was written to fill the gap. Though primarily intended for psychiatrists, the book should prove very useful to any student of the behavioural sciences who wants a simple introductory course on the principles of experimental design and data analysis. It must be one of the simplest textbooks on elementary statistics ever written.

I am indebted to the literary executor of the late Sir Ronald A. Fisher, F.R.S., to Dr Frank Yates, F.R.S., and to Oliver \& Boyd Ltd for permission to reprint Tables 3 and 5 from their book Statistical Tables for Biological, Agricultural and Medical Research.

I am also indebted to Professcr E. S. Pearson on behalf of the B ometrika trustees, for permission to reproduce in abridged form Tab'e 8 frcm E. S. Pearson and H. O. Hartley, Biometrika Tables for Statisticians Volume 1, Cambr:dge University Press, 1954.

Finally I would like to thank Professor W. M. O'Neil for several suggestions aimed at clarifying the text and Miss Nina Aitken who typed the manuscript with consummate care. 